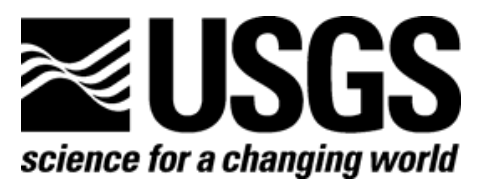

\title{
Digital data from the Questa-San Luis and Santa Fe East helicopter magnetic surveys in Santa Fe and Taos Counties, New Mexico, and Costilla County, Colorado.
}

By Viki Bankey, V.J.S. Grauch, B.J. Drenth, and Geophex, Ltd.

Prepared in cooperation with the New Mexico Office of the State Engineer, New Mexico Bureau of Geology \& Mineral Resources, and Santa Fe County

Open-File Report 2006-1170 


\section{U.S. Department of the Interior \\ Dirk A. Kempthorne, Secretary}

\section{U.S. Geological Survey \\ P. Patrick Leahy, Acting Director}

U.S. Geological Survey, Reston, Virginia 2006

Revised and reprinted: 2006

For product and ordering information:

World Wide Web: http://www.usgs.gov/pubprod

Telephone: 1-888-ASK-USGS

For more information on the USGS - the Federal source for science about the Earth, its natural and living resources, natural hazards, and the environment:

World Wide Web: http://www.usgs.gov

Telephone: 1-888-ASK-USGS

Any use of trade, product, or firm names is for descriptive purposes only and does not imply endorsement by the U.S. Government.

Although this report is in the public domain, permission must be secured from the individual copyright owners to reproduce any copyrighted material contained within this report. 


\title{
Digital data from the Questa-San Luis and Santa Fe East helicopter magnetic surveys in Santa Fe and Taos Counties, New Mexico, and Costilla County, Colorado.
}

\author{
By Viki Bankey', V.J.S. Grauch', B.J. Drenth', and Geophex, Ltd. ${ }^{2}$
}

\begin{abstract}
This report contains digital data, image files, and text files describing data formats and survey procedures for aeromagnetic data collected during high-resolution aeromagnetic surveys in southern Colorado and northern New Mexico in December, 2005. One survey covers the eastern edge of the San Luis basin, including the towns of Questa, New Mexico and San Luis, Colorado. A second survey covers the mountain front east of Santa Fe, New Mexico, including the town of Chimayo and portions of the Pueblos of Tesuque and Nambe.

Several derivative products from these data are also presented as grids and images, including reduced-to-pole data and data continued to a reference surface. Images are presented in various formats and are intended to be used as input to geographic information systems, standard graphics software, or map plotting packages.
\end{abstract}

\section{Introduction}

This report describes data collected from high-resolution aeromagnetic surveys flown over the east-central San Luis basin and the southeastern Española basin during December, 2005, by Geophex, Ltd., on contract to the U.S. Geological Survey (USGS). One survey, Questa-San Luis, covers the eastern edge of the San Luis basin, including the towns of Questa, Taos County, New Mexico, and San Luis, Costilla County, Colorado (fig. 1). A second survey, Santa Fe East, covers the mountain front east of Santa Fe, Santa Fe County, New Mexico, including the town of Chimayo and portions of the Pueblos of Tesuque and Nambe (fig. 2).

These surveys were designed to complete or extend the coverage of surveys previously acquired in the central San Luis basin (Bankey and others, 2005), the southern Española basin (USGS and others, 1999), and along the eastern borders of the San Luis Basin over the vicinities of Taos, New Mexico (Bankey and others, 2004a), and Blanca, Colorado (Bankey and others, 2004b). Our overall objective in conducting these surveys is to improve knowledge of the subsurface geologic framework in order to understand ground-water systems in populated alluvial basins along the Rio Grande. These USGS efforts are conducted in collaboration with other federal, state, and local governmental entities where possible. Additional funding was provided by the New Mexico

\footnotetext{
${ }^{1}$ U.S. Geological Survey, Denver, CO.

${ }^{2}$ Contractor, Raleigh, NC.
} 
Office of the State Engineer, Santa Fe County, and Taos County through a grant to the New Mexico Bureau of Geology and Mineral Resources from the Healy Foundation.

\section{Organization of Data}

The "readme.txt" file provides summaries of the file contents. The folders are organized as follows. Files pertaining to this report are contained in the "report" folder; files pertaining to the gridded data are contained in the "grids" folder; files pertaining to the flight-line data are contained in the "linedata" folder; and files pertaining to the color shaded relief images are contained in the "images" folder. In the data folders, ASCII files with the extension ".txt" describe the format and contents of the data files. Please read the ".txt" files before using the data files.

\section{Description of Data}

Aeromagnetic data are collected using airborne geophysical sensors that measure subtle variations in the Earth's magnetic field. Aeromagnetic surveys are designed to map the variations caused by the irregular distribution of naturally occurring magnetic minerals associated with geologic features. High-resolution surveys are flown closer to the ground and with narrower line spacing than conventional aeromagnetic surveys to better detect weakly magnetic rocks and sediments. Mapping the three-dimensional distribution of these features underground helps scientists understand the geologic controls on regional ground-water systems.

The aeromagnetic surveys (figs. 1 and 2) employed a helicopter flying along traverse lines oriented east-west, spaced $200 \mathrm{~m}$ (about $650 \mathrm{ft}$ ) apart, and flown a nominal 130-150 m (426- 492 $\mathrm{ft})$ above ground. Orthogonal lines were flown north-south at a 1,500 m (4,920 ft) spacing. Total flight-line coverage was 3,904 km (2,440 mi) for Questa-San Luis and 3,344 km (2,090 mi) for Santa Fe east. The east-west orientation of traverse lines was chosen because it is oblique to the predominant northerly geologic strike of the area. The flight-line data from the contractor are included in this report. Contractor-provided details of the flight specifications, survey procedures, and data processing are included in Appendix A.

Topographic and radar-altimeter gridded data are also provided. The topographic grid was created from 1-arc-second $(30 \mathrm{~m})$ digital elevation data that were resampled to $50 \mathrm{~m}$. The radar altimeter data were smoothed using a running average before gridding to minimize irregularities caused by variations in vegetative cover or sensor orientation.

\section{Data Processing}

Initial data processing and data reduction were accomplished by the contractor (Appendix A). The additional data and grid processing described in this section was done to display maximum detail while removing unwanted noise and simulating a flying surface draped at a consistent level over terrain.

A linear interpolation was made to the contractor's radar altimeter channel to generate a radar value at each magnetometer measurement. Radar values at the ends of flight lines, commonly erroneous, were eliminated (producing channel 'raltl_trim') and a running-average filter was applied to eliminate high-frequency noise in the radar values (producing channel 'radar_sm'),

The Questa-San Luis magnetic data required extra processing prior to gridding. Some flight lines displayed undetermined instrument noise of 1 to $3 \mathrm{nT}$ amplitude, with wavelengths spanning about 80 sample points. These effects were minimized by applying a one-dimensional Fast Fourier transform (FFT) low-pass filter to 62 affected lines. 
The magnetic and smoothed radar data were interpolated onto a grid at $50 \mathrm{~m}$ intervals. Map projection is Universal Transverse Mercator (UTM), zone 13 (central meridian of $105^{\circ} \mathrm{W}$ longitude, a false easting of 500,000 m, a false northing of $0 \mathrm{~m}$ ), and North American Datum of 1927 (NAD27).

Low-amplitude data mismatches between flight lines commonly remain after gridding. This type of noise appears as east-west linear "corrugations" in the grid. To minimize this noise without removing significant geologic effects, the data were microlevelled following the procedure implemented in OASIS Montaj ${ }^{\mathrm{TM}}$. A high-pass Butterworth filter was first applied to the gridded magnetic data perpendicular to the flight line direction using a wavelength cut-off of four times the flight-line spacing. Inspection of the resulting high-pass grid suggested that values above 2 nanoTeslas (nT) were due to geologic signal rather than noise. After limiting the values removed by the high-pass filter to no greater than $2 \mathrm{nT}$, the values were subtracted from the original flightline data to derive a microlevelled channel in the flight-line database. The microlevelled data were then gridded as the final total-field magnetic anomaly grid.

To enhance details and provide better consistency for interpretation, the final magnetic grid was continued to a simulated flight surface of $100 \mathrm{~m}$ above the ground, using the draping method of Cordell (1985). A digital elevation grid is provided to represent the ground surface. In this continuation method, the continued data are extrapolated from a series of parallel continuation surfaces that have each been computed using standard FFT techniques. The grid of smoothed radar-altimeter values determined the distances to upward or downward continue the data to a common terrain clearance of $100 \mathrm{~m}$.

Supplementary filtering was required to minimize noise that was enhanced during continuation. First, additional decorrugation filtering was applied, following the method of Urquhart (1988), modified for use with a Blackman window (Oppenheim and Schafer, 1975; described in Sweeney and others, 2002). A Blackman window with a filter of 11 grid points was convolved with data along the grid rows (the direction of the traverse lines), resulting in both a high-pass grid and a low-pass grid. The same Blackman window was then convolved with the data along the columns of the low-pass grid (the direction orthogonal to the traverse line) to remove flight-line "corrugations". The high-pass grid was added to this filtered grid to retain the shortwavelength information in the direction of the flight lines.

Residual high-frequency noise that didn't necessarily correlate with the flight-line direction was removed by applying a low-pass, eighth-order Butterworth filter with a cut-off wavelength of $120 \mathrm{~m}$ to the decorrugated magnetic anomaly grid. This wavelength is slightly greater than the minimum sampling (or Nyquist) wavelength of two times the grid interval.

Finally, a standard reduction-to-pole operator was applied to the grid. This operation, resulting in reduced-to-pole (RTP) data, corrects for shifts of the main anomaly from the center of the magnetic source that occur at most latitudes owing to the oblique orientation of the measured magnetic field with respect to the Earth's surface (the field is vertical only at the magnetic poles). Declination and inclination of the Earth's field were assumed to be $10^{\circ}$ and $64^{\circ}$ for Questa-San Luis and $11^{\circ}$ and $63^{\circ}$ for Santa Fe east surveys. To apply the reduced-to-pole transformation, one must assume that the total magnetizations of most rocks in the study area align parallel or anti-parallel to the Earth's main field Based on considerations of rock type and age in the area, this assumption is generally valid (Grauch and others, 2004). 


\section{Acknowledgments}

We are thankful to the people of southern Colorado and northern New Mexico for their tolerance during the low-level flying over their homes and businesses. We also thank the Pueblos of Nambe and Tesuque for their cooperation during flying.

Additional funding was provided by the New Mexico Office of the State Engineer, Santa Fe County, and Taos County through a grant to the New Mexico Bureau of Geology and Mineral Resources from the Healy Foundation.

\section{References Cited}

Bankey, Viki, Grauch, V.J.S., and Fugro Airborne Surveys Corp., 2004a, Digital aeromagnetic data and derivative products from a helicopter survey over the town of Taos and surrounding areas, Taos County, New Mexico: U.S. Geological Survey Open-File Report 2004-1229A, CD-ROM.

Bankey, Viki, Grauch, V.J.S., and Fugro Airborne Surveys Corp., 2004b, Digital aeromagnetic data and derivative products from the Blanca airborne survey, covering areas in Costilla and Alamosa County, Colorado: U. S. Geological Survey Open-file Report 2004-1229B, CD-ROM.

Bankey, Viki, Grauch, V.J.S., Webbers, Ank, and PRJ, Inc., 2005, Digital data and derivative products from a high-resolution aeromagnetic survey of the central San Luis basin, covering parts of Alamosa, Conejos, Costilla, and Rio Grande Counties, Colorado, and Taos County, New Mexico: U. S. Geological Survey Open-file Report 2005-1200, CD-ROM.

Cordell, L., 1985, Techniques, applications, and problems of analytical continuation of New Mexico aeromagnetic data between arbitrary surfaces of very high relief, Proceedings of the International Meeting on Potential Fields in Rugged Topography, Institute of Geophysics, University of Lausanne, Switzerland, Bulletin no. 7, p. 96-101.

Grauch, V.J.S., Bauer, P.W., and Kelson, K.I., 2004, Preliminary interpretation of high-resolution aeromagnetic data collected near Taos, New Mexico: New Mexico Geological Society Guidebook 55, p. 244-256.

Oppenheim, A.V., and Schafer, R.W., 1975, Digital signal processing, 1st edition: Prentice-Hall, Inc., $585 \mathrm{p}$.

Sweeney, R. E., Grauch, V. J. S., and Phillips, J. D., 2002, Merged digital aeromagnetic data for the Albuquerque and southern Española Basins, New Mexico: U. S. Geological Survey Open-file Report 02-205, 15 p., http://pubs.usgs.gov/of/2002/ofr-02-0205/.

U.S. Geological Survey, Sander Geophysics, Ltd., and Geoterrex-Dighem, 1999, Digital aeromagnetic data from the Sandoval-Santa Fe, Belen, and Cochiti airborne surveys: U. S. Geological Survey Open-file Report 99-0404, CD-ROM.

Urquhart, T., 1988, Decorrugation of enhanced magnetic field maps: Expanded Abstracts and Biographies, Society of Exploration Geophysicists 58th Annual Meeting, Anaheim, CA, 1988, p. 371-372. 


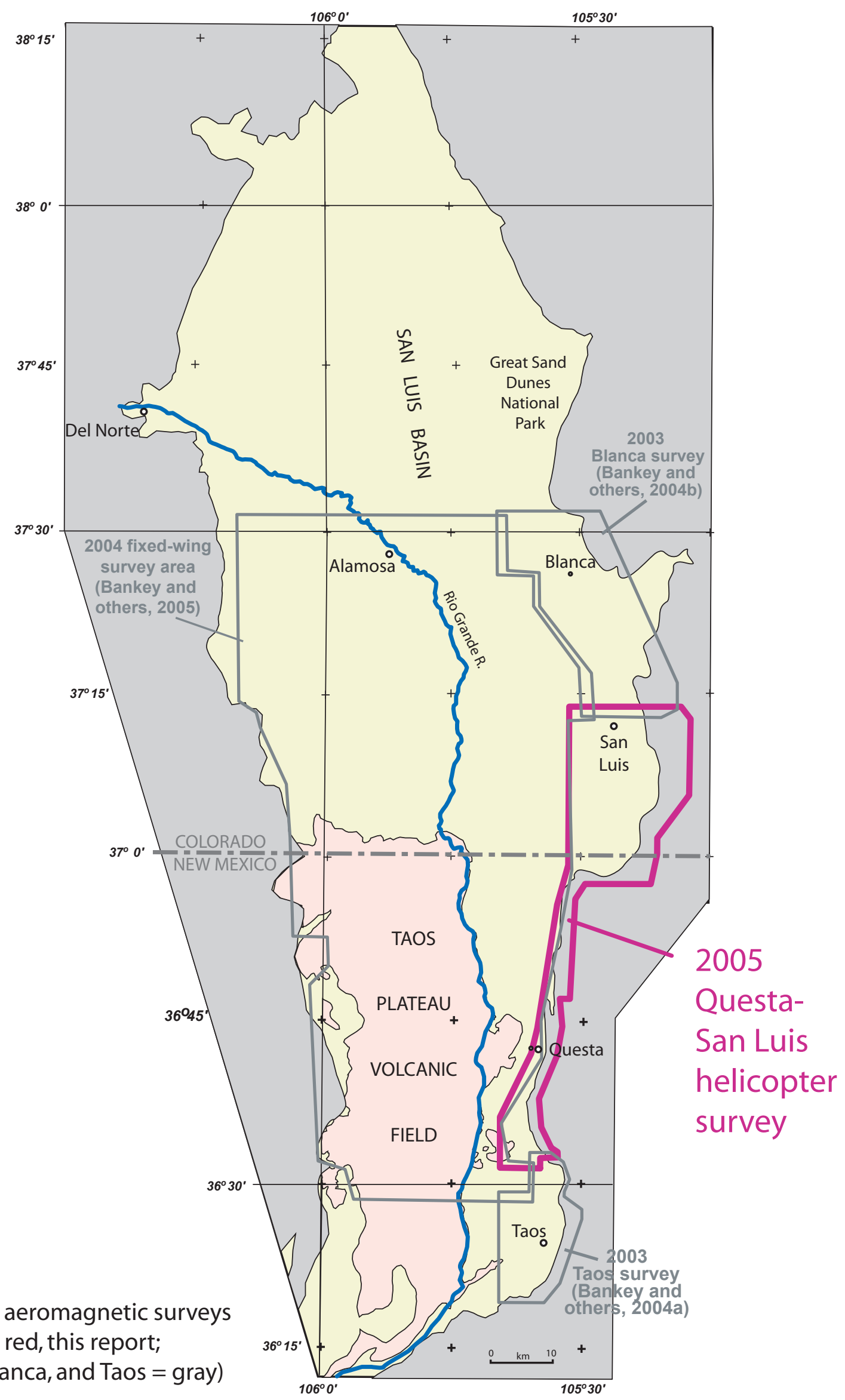




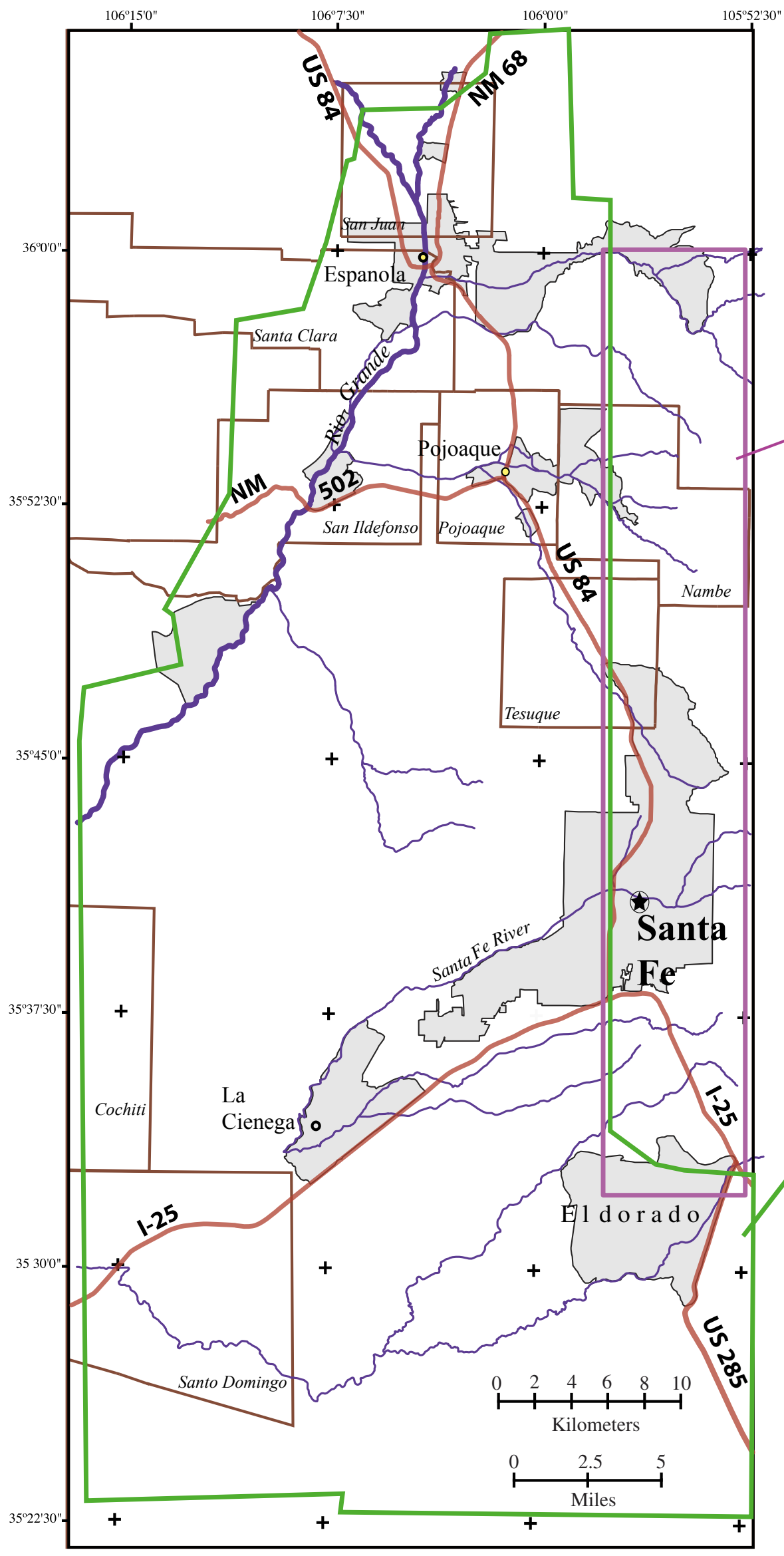

HELICOPTER SURVEY SANTA FE EAST 2005

\section{S. Española Basin} Survey (USGS and others, 1999)

Figure 2. Location of Santa Fe East aeromagnetic survey 